\title{
Abbreviations
}

The following abbreviations are used in the notes and bibliography.

BLvs Bibliothek des litterarischen Vereins in Stuttgart

CC Corpus Christianorum

CSEL Corpus Scriptorum Ecclesiasticorum Latinorum

GAG Göppinger Arbeiten zur Germanistik

LCL Loeb Classical Library

MGH Monumenta Germaniae Historica

PG Patrologia cursus completus. Series Graeca, ed. J. P. Migne, 16I vols. (Paris, I857-66).

PL Patrologia cursus completus. Series Graeca, ed. J. P. Migne, 221 vols. (Paris, 1844-55). 



\section{Images of the Medieval Peasant}

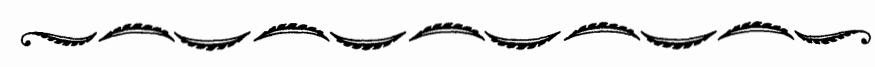


